\title{
Basal Cell Carcinoma: An Unusual Localization and a Typical Dermoscopy
}

Aicha Nassiri*, Kaoutar Moustaide, Niema Aqil, Salim Gallouj and Fatima Zahra Mernissi

Hassan II Hospital, Road of Sidi Hrazem, FES, Morocco
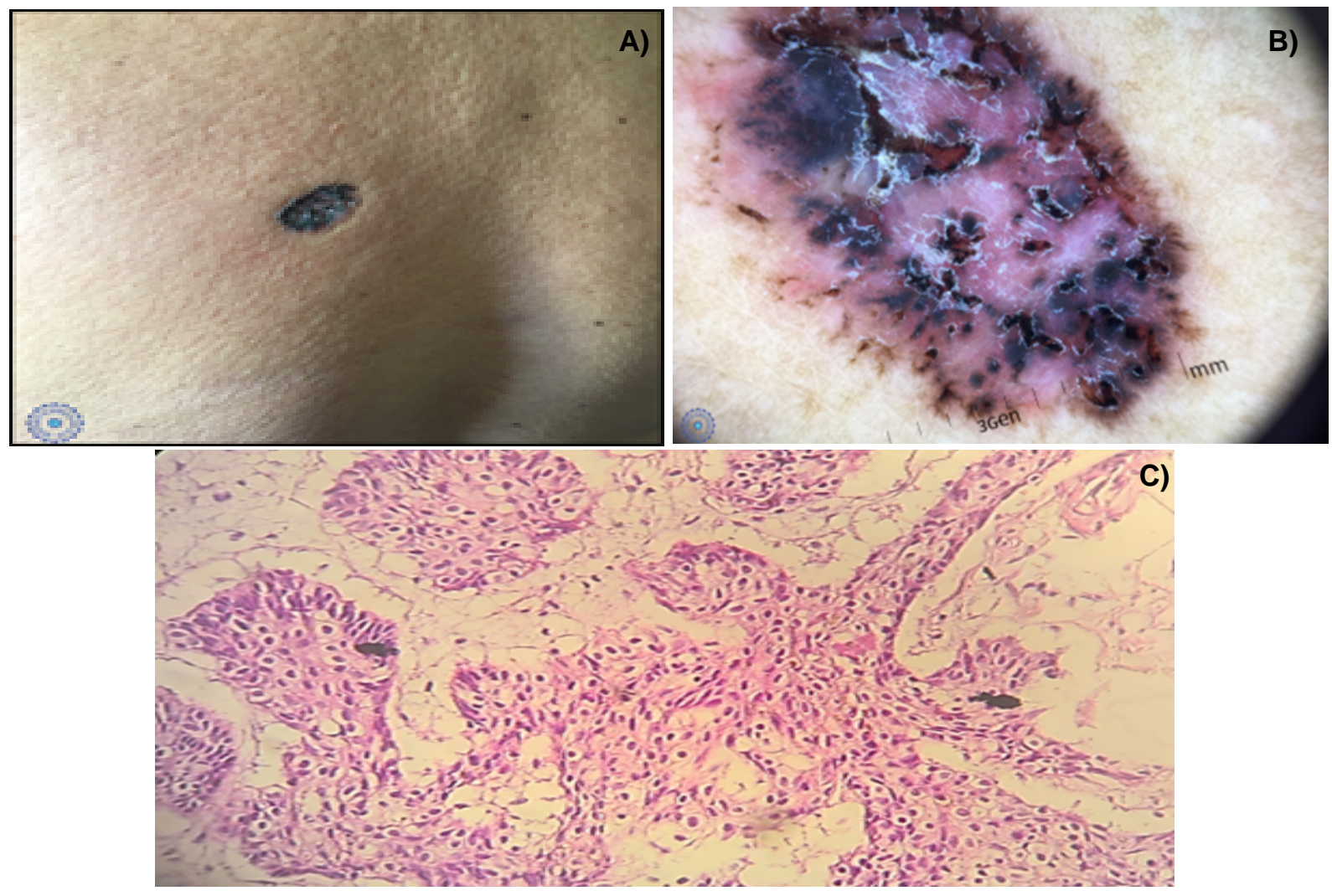

Figure 1: A) A $3 \mathrm{~cm}$ pigmented oval plaque on the back; B,C) On dermoscopy screening maple leaf-like area, spoke wheel areas, bluegray nests, gray-blue globules, pink white area, digitiform structures seen.

\section{Clinical Image}

Basal cell carcinoma is a frequent disease that can be caused by chronic exposition to UV radiation. Dermoscopy is a very helpful device that can lead to diagnosis. Mr. M.G is 63-years-old man that presents a rough pigmented plaque on the back since more than 5 years. Recently it becomes slightly itchy. Clinically: A $3 \mathrm{~cm}$ pigmented oval plaque on the back. On dermoscopy screening maple leaf-like area, spoke wheel areas, blue-gray nests, gray-blue globules, pink white area, digitiform structures seen. We removed the lesion with $5 \mathrm{~mm}$ of margin. The histopathology concluded to a nodular basal cell carcinoma with healthy margin. The patient was advised to apply photo protection measures and a follow-up once a year (Figure 1).

\section{Keywords:}

Pigmented basal cell carcinoma; Diagnosis; Dermoscopy

*Corresponding author: Aicha Nassiri, Hassan II Hospital, Road of Sidi Hrazem, FES, Morocco, E-mail: aichanassiri6@gmail.com

Citation: Nassiri A, Moustaide K, Aqil N, Gallouj S, Mernissi FZ (2019) Basal Cell Carcinoma: An Unusual Localization and a Typical Dermoscopy . Int J Clin Med Imaging 6: 628. doi:10.4172/2376-0249.1000628

Copyright: (C) 2019 Nassiri A et al. This is an open-access article distributed under the terms of the Creative Commons Attribution License, which permits unrestricted use, distribution, and reproduction in any medium, provided the original author and source are credited. 